\title{
The inhibition of biodegradation on building limestone by plasma etching
}

\author{
Yufan Ding ${ }^{1,2}$, Ana Teresa Caldeira ${ }^{1,2}$, Catia Salvador ${ }^{1}$, Sabrina Grassini ${ }^{3}$, Emma Angelini ${ }^{3}$, Nick \\ Schiavon ${ }^{1^{*}}$ \\ ${ }^{1}$ Hercules Laboratory, Universidade de Evora, 7000-809 Evora, Portugal \\ 2 Department of Chemistry, Universidade de Évora, 7000 Évora, Portugal \\ 3 Politecnico di Torino, Turin, Italy
}

\begin{abstract}
Plasma etching is an innovative technique that has been recently applied in the cleaning of soiled archaeological objects. This research investigated the use of low-pressure plasma etching in cleaning microbial contaminations on an oolitic limestone from an UNESCO World Heritage listed monument: the Batalha Monastery in Central Portugal. The cleaning effect was assessed by FTIR, SEM, optical microscope, and cell viability index measurement. Experimental work suggests that plasma discharge can cause rupture in the microbial cell structures and is helpful in removing microorganisms from the surface of the stone. At the macroscopic level, detachment of microbial crust was also observed in plasma etched bio-deteriorated limestone surfaces. Furthermore, plasma etching can inhibit the microbial growth by decomposing and eliminating the sugar-containing compounds on the limestones, thus eliminating a major nutrient supply for microbial metabolism and reproduction. Plasma etching can therefore be regarded as a fast and eco-friendly conservation tool for stone heritage architecture to prevent/reduce the onset of bio-colonization and biodegradation.
\end{abstract}

\section{Section: RESEARCH PAPER}

Keywords: Plasma cleaning; cultural heritage conservation; limestone; microbial contamination; Batalha Monastery

Citation: Yufan Ding, Ana Teresa Caldeira, Catia Salvador, Sabrina Grassini, Emma Angelini, Nick Schiavon, The inhibition of biodegradation on building limestone by plasma etching, Acta IMEKO, vol. 10, no. 3, article 29, September 2021, identifier: IMEKO-ACTA-10 (2021)-03-29

Section Editor: Francesco Lamonaca, University of Calabria, Italy

Received August 19, 2021; In final form August 24, 2021; Published September 2021

Copyright: This is an open-access article distributed under the terms of the Creative Commons Attribution 3.0 License, which permits unrestricted use, distribution, and reproduction in any medium, provided the original author and source are credited.

Funding: This work was supported by the European Union's Horizon 2020 research and innovation programme under the Marie Skłodowska-Curie grant agreement No. 766311.

Corresponding author: Nick Schiavon, e-mail: schiavon@uevora.pt

\section{INTRODUCTION}

During the aging of cultural heritage objects, stone artifacts may undergo decay under the effects of different kinds of contamination. Through dry and wet depositional processes, soil dust, insects, mildew, fungi and gaseous and particulate air pollutants accumulate on stone surface building up patinas and crusts, which are difficult to remove without damaging the original substrate [1]-[3]. Conventional cleaning methods often fail to completely remove these surface soiled patinas and/or biofilms by using toxic and aggressive chemicals that may leave undesired residues [4], [5]. In the literature, the possible use of plasma cleaning for the restoration and preservation of various materials such as wood, paper, fabric, metals, glasses, ceramics and stones has been reported. Plasma etching, for instance, was used in an attempt to remove: a) varnish (lacquer) coating on paintings using oxygen plasma [6]; b) epoxy / acrylic resin on stones by using compressed air or mix of oxygen and argon plasma [7], [8]; c) cleaning patinas on metal artefacts using hydrogen plasma [9]. It was proved that plasma can successfully remove the above-mentioned contaminations without damaging the substrate.

Plasma removes the surface contamination via three different reactions: (a) ion sputtering - atoms on the surface can be sputtered non-selectively when the floating potential of the plasma ions is beyond substrate - surface binding threshold; (b) radicals etching - atoms or radicals from the plasma chemically react with the surface, volatile reaction products can be eliminated through pumping. The choice of the gas mixture used for etching is determined by the volatility and stability of the etched products. For Si-rich materials, halogen-, hydride-, and methyl compounds can be used. For an effective removal of 


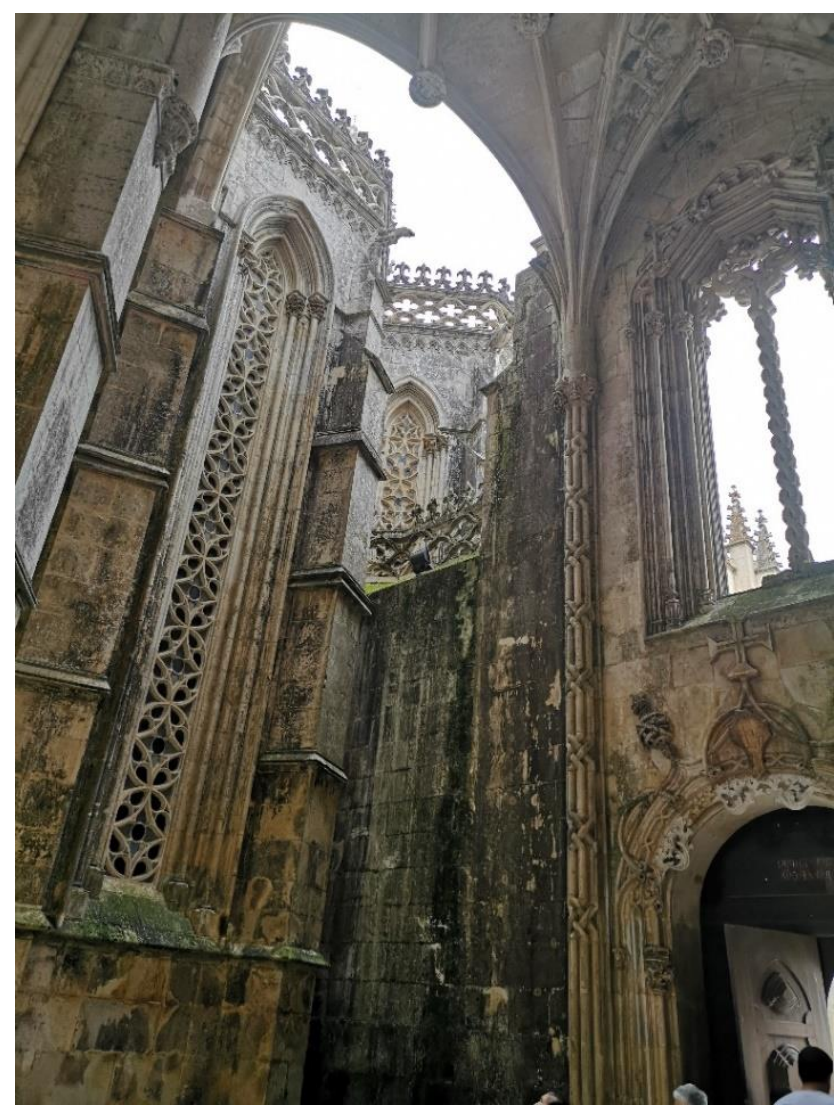

Figure 1. Bio-degradation on the inner wall of the "imperfect chapels" of the Batalha Monastery.

organic compounds, oxygen can be used; (c) heating - the surface immersed in the plasma is heated mainly by electron, ion bombardment, and plasma radiation [10]. In the study of Liqing Yang et al [11] , a self-designed radio-frequency (RF) glow discharge oxygen plasma was used to sterilize the Pseudomonas aeruginosa on the polyethylene terephthalate (PET) sheets, the germicidal effect is a function of treating time and distance from the induction coil. The sterilization mechanism analyzation demonstrated that intense etching action of electrons and ions on cell membrane engenders bacteria death in the plasma active discharge area, while in the plasma afterglow area attacking polyunsaturated fatty acids in the cell membrane by high concentration oxygen radicals becomes the main factor of bacteria death.

The type of plasmas applied for cleaning can be classified into several categories depending on their operating principle: a) dielectric barrier discharge (DBD), in which the discharge is generated in a cylindrical system at the atmospheric pressure: it consists of a tube made with dielectric material (fused silica), the high voltage electrode (brass) is a ring placed over the tube and the rod ground electrode is placed in the middle of this tube with gas inlet, driving the plasma to the environmental air [12]; b) corona discharge initiates the plasma between the internal pinshaped electrode and the cylinder/truncated cone shaped external electrode (nozzle) which is made with stainless steel and is replaceable, when the nozzle is open, coronal filaments brings out a gas flow with the leaving plasma flowing freely [13]. c) arc discharge generates thermal plasma by compressed air, it can reaches working temperature exceeding $300^{\circ} \mathrm{C} \sim 400^{\circ} \mathrm{C}$, with short treating time [8], [14]; d) capacitive coupled plasma has a vacuum chamber, with inlet for selective gas (inert, oxidic or reductive) that generates ions and react with the sample, two discal-shaped electrodes are placed at the top and the bottom, with sample placed in between [15]. Atmospheric plasma treatment has been shown to be able to remove biofilms on artificial substrates such as polystyrene wafers and stainless steel [16], [17], while $\mathrm{He} / \mathrm{O}_{2}$ plasma jet was found to have antimicrobial effects on some bacterial biofilms [18].

This study aims to investigate the effectiveness of plasma etching in the removal of microbials from bio-deteriorated limestone surfaces in monuments and buildings and in the prevention of microorganism growth, in order to provide conservators with a feasible and effective solution for preserving stone monuments in both urban and rural environments. The Batalha Monastery (Figure 1), a UNESCO listed World Heritage site located in central Portugal and built with locally quarried Jurassic oolitic limestone [19], was chosen for this investigation. The Monastery oolitic limestone has suffered and still is suffering from severe biodeterioration caused by extensive lichenous crusts and microorganism biofilms growing on the building surface: this promotes both physical and chemical attack on the limestone substrate via hyphae mechanical penetration along calcite inter-crystalline spaces, dissolution/leaching of calcite minerals, and precipitation of secondary minerals such as $\mathrm{Ca}$ oxalates within the stone porosity framework [3].

\section{MATERIALS AND METHODS}

\subsection{Preparation of stone tablets}

Limestones were collected from five quarries which supplied the oolitic limestone used in the building and restoration of the Batalha Monastery: Pidiogo (39॰39'15.7"N 844'27.9"W), Valinho do Rei (39॰39'32.5"N 844'58.1"W), Reguengo do Fetal $\left(39^{\circ} 38^{\prime} 43.64^{\prime \prime} \mathrm{N} \quad 8^{\circ} 45^{\prime} 16.19^{\prime \prime} \mathrm{W}\right), \quad$ Cabeço do Roxo $\left(39^{\circ} 35^{\prime} 39.84^{\prime \prime N} 8^{\circ} 51^{\prime} 27.19^{\prime \prime} \mathrm{W}\right)$ and Outeiro de Sebastião (39॰35'38.89"N 851'27.49"W) [19]. The stones were cut into $2 \mathrm{~cm}$ (width) $\times 2 \mathrm{~cm}$ (length) $\times 1 \mathrm{~cm}$ (height) tablets, washed and dried under $60^{\circ} \mathrm{C}$ for $24 \mathrm{~h}$, then sterilized.

\subsection{Extraction, cultivation and incubation of microbials}

Sampling was performed on representative areas of the stone materials of the Batalha Monastery, including areas with evidence of alterations. Microinvasive (chisel and scalpels) and noninvasive (swabs) methods were applied during the samples' collection, performed with sterile material but in outdoor environment. The extracted microorganism was stored in falcon tube, being immersed by saline solution.

For bacterial and fungal growth, malt extract (ME) medium was prepared with $20 \mathrm{~g} / \mathrm{L}$ malt extract, $20 \mathrm{~g} / \mathrm{L}$ glucose and $1 \mathrm{~g} / \mathrm{L}$ peptone, then sterilized in autoclave for $20 \mathrm{~min}$ at $120^{\circ} \mathrm{C}$ and 1.5 bars. $1 \mathrm{~mL}$ of saline medium which contains the collected microorganism and add it into $500 \mathrm{~mL} \mathrm{ME}$ medium, this culture was then incubated for $72 \mathrm{~h}$ in an incubator with controlled temperature of $28^{\circ} \mathrm{C}$ and with orbital agitation at $150 \mathrm{rpm} .1 \mathrm{~mL}$ of mixed culture was used to inoculate each limestone tablet in 2.1. Then all tablets were incubated in the ARALAB Plant Growth Chamber for 15 days, with controlled temperature at $28{ }^{\circ} \mathrm{C}$, humidity at $81.0 \% \mathrm{rH}$, and $10 \%$ illumination of $4 \times 18 \mathrm{~W}$ fluorescent.

\subsection{Plasma etching of bio-incubated samples}

The cleaning treatments were carried out in a self-build capacitively coupled parallel-plate reactor (Figure 2). The reactor employs a two-electrodes configuration; the upper electrode is connected to a radio frequency (RF) (13.56 MHz) power supply 


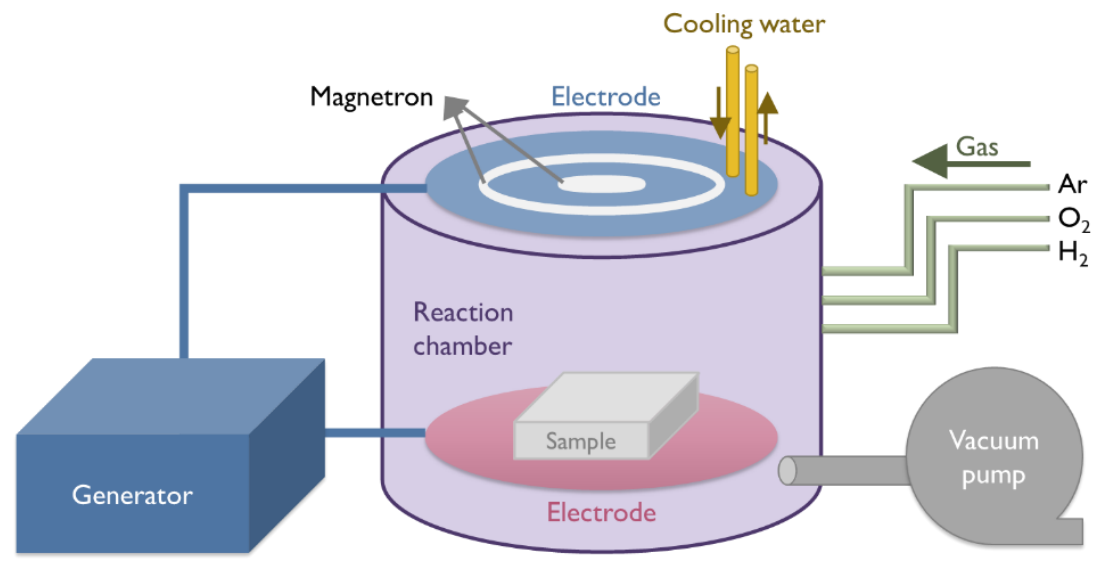

Figure 2. Schematic of the coupled parallel-plate plasma reactor.

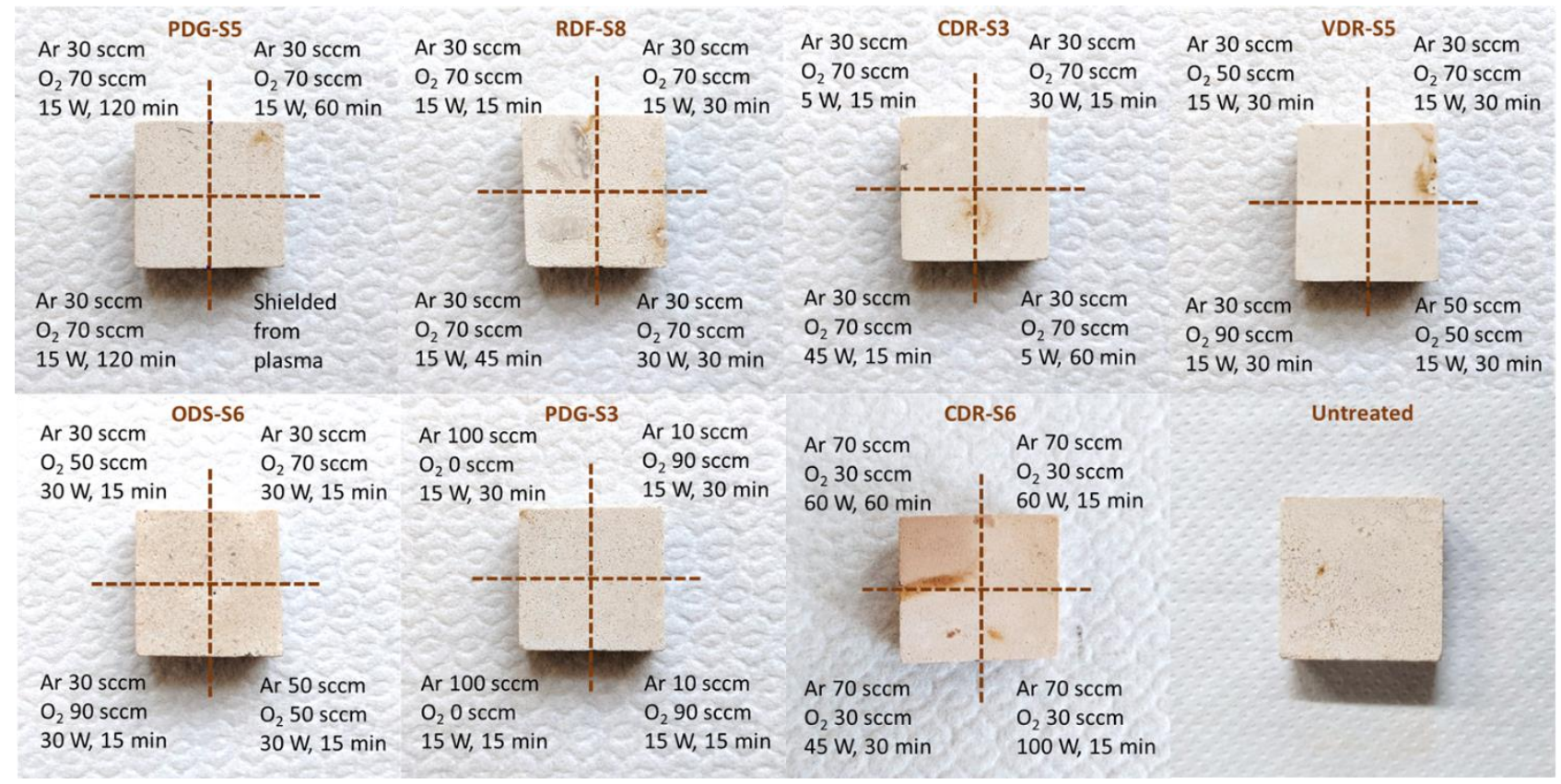

Figure 3. Different areas of the tablets treated by plasma in different experimental conditions.

through an impedance matching unit, while the bottom electrode is connected to the ground [20]. The etching treatments were performed by positioning the samples on the ground electrode in a plasma fed with $\mathrm{Ar}\left(99.99 \%\right.$ purity) and $\mathrm{O}_{2}$ (99.99\% purity) in different ratios (with absolute flows in the range of 10 to 100 sccm - standard cubic centimeter per minute, respectively), at input power in the range of $15 \mathrm{~W}$ to $60 \mathrm{~W}$, for a maximum treatment time of 120 minutes.

Figure 3 shows the tablet areas with corresponding treatment settings. An area of the sample surface is shielded from the plasma, in order to compare the surface chemistry and morphology with other areas exposed to the plasma, and before and after plasma etching.

\subsection{Assessment of plasma treatment}

\subsubsection{Attenuated Total Reflectance-Fourier Transform Infrared Spectroscopy (ATR-FTIR)}

The FTIR spectra were recorded by Perkin Elmer Spectrum 2000 FTIR spectrometer (Perkin Elmer, Norwalk, CT, USA) equipped with a single reflection attenuated total reflectance (ATR) accessory. For each sample, 16 scans were recorded with resolution of $4 \mathrm{~cm}^{-1}$ [21].

\subsubsection{SEM and Bright Field Microscope}

Scanning electron microscopy coupled with energy-dispersive X-ray spectrometry was carried out using a Hitachi S3700N (Tokyo, Japan) SEM coupled to a Bruker (Karlsruhe, Germany) XFlash 5010 SDD Detector system. Operating conditions were as follows: backscattered imaging detector (BSEM); low-vacuum mode (pre-set pressure of $40 \mathrm{~Pa}$ ) allowing the observation of non-coated biological samples; accelerating voltage: $20 \mathrm{kV}$; current: $120 \mathrm{~mA}$. For surface observation, the plasma-treated and plasma-untreated tablets $(2 \mathrm{~cm} \times 2 \mathrm{~cm} \times 1 \mathrm{~cm})$ were put into the chamber directly. Samples were also observed under LEICA M205C Stereo Microscope (Leica, Wetzlar, Germany), photos were taken by a uEyeUI 149xSE-Cindustrial camera (IDS, Obsesulm, Germany).

\subsubsection{Cell viability index}

Cell viability index (CVI) of the bio-contaminants present in samples was assessed by the 3-(4,5-dimethylthiazol-2-yl)-2,5diphenyltetrazolium bromide (MTT) adapted for cultural heritage materials [22], [23]. Use $500 \mu \mathrm{L}$ sterile water to extract the microorganisms from the tablet surface, then $90 \mu \mathrm{L}$ of each 
extracted suspension from stone were incubated with $300 \mu \mathrm{L}$ of MTT solution $(0.5 \mathrm{mg} / \mathrm{mL})$ for $4 \mathrm{~h}$, at $37^{\circ} \mathrm{C}$ in the dark. After this, the suspensions were centrifuged at $10000 \mathrm{rpm}$ for $15 \mathrm{~min}$ and the supernatants were removed and discarded. Then $100 \mu \mathrm{L}$ of DMSO/ethanol (1:1) was added to promote the dissolution of the formazan crystals formed. The final suspension was centrifuged at $10.000 \mathrm{rpm}$ for $15 \mathrm{~min}$ and the absorbance of the supernatant was determined by spectrophotometry at $570 \mathrm{~nm}$. Each assay was performed in triplicate.

\section{RESULTS AND DISCUSSION}

\subsection{FTIR spectra and sugar decomposition}

The FTIR spectra of plasma-treated and plasma-untreated samples are reported in Figure 4. Limestone tablets before bioincubation are characterized by peaks at $2514 \mathrm{~cm}^{-1}, 1795 \mathrm{~cm}^{-1}$, $1396 \mathrm{~cm}^{-1}, 872 \mathrm{~cm}^{-1}, 712 \mathrm{~cm}^{-1}$, which are typical bands of lowmagnesium calcite [RRUFF ID: R040070.1] [24]-[26]. Peaks at $1070 \mathrm{~cm}^{-1}$ and $782 \mathrm{~cm}^{-1}$ represent quartz [RRUFF ID:
R040031.1]. After bio-incubation, aside from the calcite and quartz, the presence of peaks at $3278 \mathrm{~cm}^{-1}, 2925 \mathrm{~cm}^{-1}, 1637 \mathrm{~cm}^{-1}$, $1320 \mathrm{~cm}^{-1}, 1030 \mathrm{~cm}^{-1}$ can also be seen, the main peak of calcite at $1396 \mathrm{~cm}^{-1}$ has become wider, a peak at $1411 \mathrm{~cm}^{-1}$ can be seen after spectrum subtraction. Among the newly added peaks, $3278 \mathrm{~cm}^{-1}$ represents $(\mathrm{O}-\mathrm{H})$ stretching peak which belongs to carbohydrate, water or organic acids, $2925 \mathrm{~cm}^{-1}$ represents $(\mathrm{C}-\mathrm{H})$ stretching band in $\mathrm{CH}_{2}$ and $\mathrm{CH}_{3}$ group, $1637 \mathrm{~cm}^{-1}$ refers to $(\mathrm{O}-\mathrm{H})$ bending, the peak at $1320 \mathrm{~cm}^{-1}$ is due to $\mathrm{O}-\mathrm{H}$ bending of the $\mathrm{C}-\mathrm{OH}$ group, $1411 \mathrm{~cm}^{-1}$ is a combination of $\mathrm{O}-\mathrm{H}$ bending of the $\mathrm{C}-\mathrm{OH}$ group and $\mathrm{C}-\mathrm{H}$ bending of the alkenes, peaks at $1031 \mathrm{~cm}^{-1}$ is due to carbohydrates and organic acid C-O, C-C stretching [27], [28]. According to the previous study, these are characteristic peaks of sugar (could be cellulose or glucose) [29].

The incubated tablets were treated by plasma in different experimental conditions: a) Ar $30 \mathrm{sccm}, \mathrm{O}_{2} 70 \mathrm{sccm}, 5 \mathrm{~W}$, $15 \mathrm{~min}$; b) Ar $10 \mathrm{sccm}, \mathrm{O}_{2} 90 \mathrm{sccm}, 15 \mathrm{~W}, 15 \mathrm{~min}$; c) Ar $30 \mathrm{sccm}$, $\left.\mathrm{O}_{2} 70 \mathrm{sccm}, 30 \mathrm{~W}, 15 \mathrm{~min} ; \mathrm{d}\right)$ Ar $30 \mathrm{sccm}, \mathrm{O}_{2} 70 \mathrm{sccm}, 15 \mathrm{~W}$,

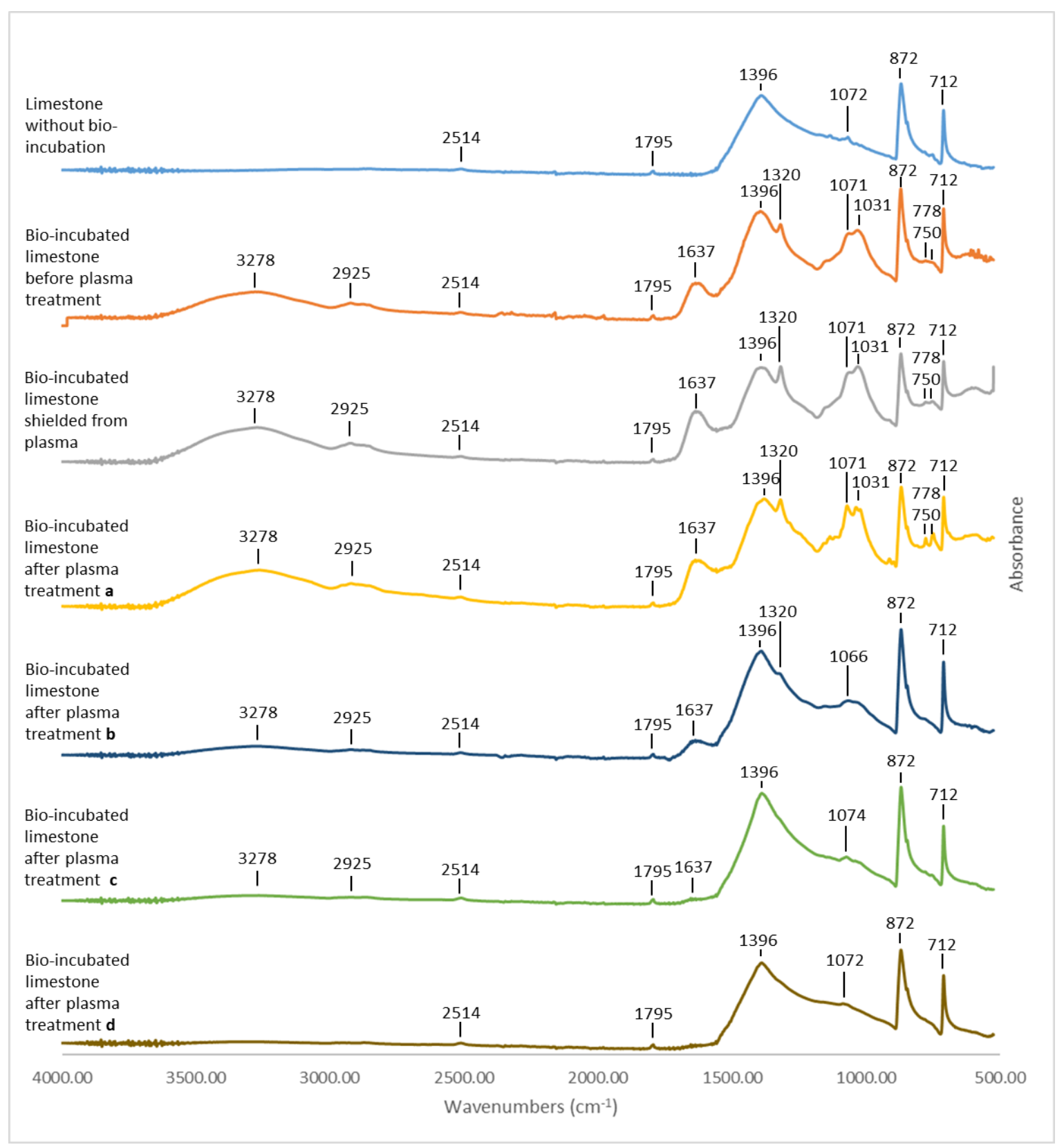

Figure 4. FTIR spectra of tablets before and after plasma etching under different experimental conditions. 
120 min. It can be seen that after plasma treatment condition b), c) and d), tablets have shown weakened or removed peaks at $3278 \mathrm{~cm}^{-1}, 2925 \mathrm{~cm}^{-1}, 1637 \mathrm{~cm}^{-1}$ and $1031 \mathrm{~cm}^{-1}$ (Figure 4), implying the removal of sugar. Area shielded from plasma does not show any weakening of the sugar related peaks, implying that only the eliminating of sugar can be realized only by exposure to plasma. Plasma etching under condition a) shows little difference than the untreated sample, for very short working time and very low working power was applied, but condition b) and c) lead to obvious weakening of the sugar peaks. Sample treated under condition d) has no characteristic peaks other than limestone.

To assess the factors that affect the cleaning results, incubated stone tablets were treated with various operating parameters of the coupled-capacitive plasma, including operation time, plasma power, gas ratio of oxygen and argon, as listed in Table 1 and Table 2. Semi-quantification of the organic substance can be done by using Beer-Lamber law:

$A=-\log _{10} \frac{I_{t}}{I_{0}}=\log _{10} \frac{1}{T}=K \cdot l \cdot c$,

where $A$ is the absorbance, $K$ is the absorptivity, 1 is the optical path length, $\mathrm{c}$ is the concentration of the attenuating species. Because $K$ and $l$ are constant for all the samples in this experiment, the organic concentration is in direct proportion to the absorbance. The cleaning efficiency is defined by the weakening of the organic-matter-related peaks: the ratio of peak intensity after treatment to the peak intensity before treatment are graded as: "O" completely removed $(<0.05)$, “ $\bullet$ " mostly

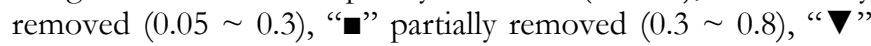
presented $(0.8 \sim 1.0)$. It can be seen that, under the same treating duration, higher power leads to better cleaning effect; under the same plasma power, longer working time performs better cleaning results. The surface cleaning effect was also influenced by the gas ratio, higher argon concentration in the plasma discharge has better performance of removing sugar, this might be interpreted that the dry corrosion by ionized argon has more intense cleaning effect for the limestone surface, instead of oxidation reaction by oxygen.

\subsection{SEM observation}

Samples with and without plasma treatment were observed by SEM and stereo microscope; SEM micrograph are shown in
Figure 5. On samples not exposed to plasma discharge, a mass of clustered and filamentous microorganisms can be clearly seen on the limestone surface Figure 5 a). Under higher magnification, interlaced filamentous microorganisms and circular cell structure (Figure $5 \mathrm{~b}, \mathrm{c}, \mathrm{d}$ ) are clearly displayed. After plasma etching, the filamentous microorganisms are mostly removed, some spotted microbial aggregation remains on the surface, mostly at the or inside of the oolites (Figure 5 e). This could be due to the loose structure inside or on the boundary of the oolites, where microbials are easy to aggregate in and difficult to remove at these inter-crystalline spaces. Circular cells are distorted and damaged (Figure $5 \mathrm{~g}$ ), or completely lysed with no structure (Figure $5 \mathrm{~h}$ ). The filamentous microorganisms are ruptured and no longer connected, leaving only remains of fractured debris (circled by the yellow dash lines in Figure $5 \mathrm{~h}$ ).

The SEM investigation shows how the plasma is capable to effectively disrupt microbial structures and remove microorganisms with the cleaning effect particularly significant on stone regions characterized by low porosity and massive texture. However, due to the non-homogenous porosity distribution in oolitic limestones, microbials remaining in cavities are not easily removed.

\subsection{Optical microscopy and appearance changing}

Observed by bright field stereomicroscope, bio-contaminated limestone shows some distinct changes after plasma cleaning (Figure 6). Before plasma etching, yellow biofilms and black mold spots were present on surface areas where microbial growth is more severe (Figure 6 a, b). White filamentous organisms also were found widely distributed over the stone surface (Figure $6 \mathrm{c}$ ) with the tablet edge being a region where the biofilm is easier to form (Figure $6 \mathrm{~d}$ ). After plasma etching, biofilms show cracking and detachment from the stone substrate (Figure $6 \mathrm{e}$ ), the color of the microbial crust was lightened, black mildews were partially faded (Figure $6 \mathrm{f}$ ), white filaments were obviously removed (Figure $6 \mathrm{~g}$ ) with the biofilm on the tablet edge also peeling off in some cases (Figure $6 \mathrm{~h}$ ).

Table 1. Effect of input power and etching time on sugar removal under fixed gas flow $\mathrm{Ar} 30 \mathrm{sccm}$ and $\mathrm{O}_{2} 70 \mathrm{sccm}$.

\begin{tabular}{|c|c|c|c|c|c|}
\hline Input power & $15 \mathrm{~min}$ & $30 \mathrm{~min}$ & $45 \mathrm{~min}$ & $60 \mathrm{~min}$ & $120 \mathrm{~min}$ \\
\hline shield from plasma & & & & & $\nabla$ \\
\hline $15 \mathrm{~W}$ & - & घ & $\bullet$ & ○ & o \\
\hline $30 \mathrm{~W}$ & $\bullet$ & $\bullet$ & & & \\
\hline $45 \mathrm{~W}$ & $\bullet$ & o & & & \\
\hline $60 \mathrm{~W}$ & $\bullet$ & & & & \\
\hline $100 \mathrm{~W}$ & $\bullet$ & & & & \\
\hline
\end{tabular}

Table 2. Effect of different gas ratios in the plasma discharge on sugar removal.

\begin{tabular}{|c|c|c|c|c|c|c|}
\hline Power and time & $\begin{array}{c}\text { Ar } 100 \mathrm{sccm} \\
\mathrm{O}_{2} 0 \mathrm{sccm}\end{array}$ & $\begin{array}{l}\text { Ar } 50 \mathrm{sccm} \\
\mathrm{O}_{2} 50 \mathrm{sccm}\end{array}$ & $\begin{array}{l}\text { Ar } 30 \mathrm{sccm} \\
\mathrm{O}_{2} 50 \mathrm{sccm}\end{array}$ & $\begin{array}{l}\text { Ar } 30 \mathrm{sccm} \\
\mathrm{O}_{2} 70 \mathrm{sccm}\end{array}$ & $\begin{array}{l}\text { Ar } 30 \mathrm{sccm} \\
\mathrm{O}_{2} 90 \mathrm{sccm}\end{array}$ & $\begin{array}{l}\text { Ar } 10 \mathrm{sccm} \\
\mathrm{O}_{2} 90 \mathrm{sccm}\end{array}$ \\
\hline $15 \mathrm{~W}, 15 \mathrm{~min}$ & $\bullet$ & & & घ & & घ \\
\hline $15 \mathrm{~W}, 30 \mathrm{~min}$ & 0 & $\bullet$ & $\bullet$ & $\bullet$ & $\bullet$ & $\bullet$ \\
\hline $30 \mathrm{w}, 15 \mathrm{~min}$ & & $\bullet$ & $\bullet$ & $\bullet$ & $\bullet$ & \\
\hline
\end{tabular}



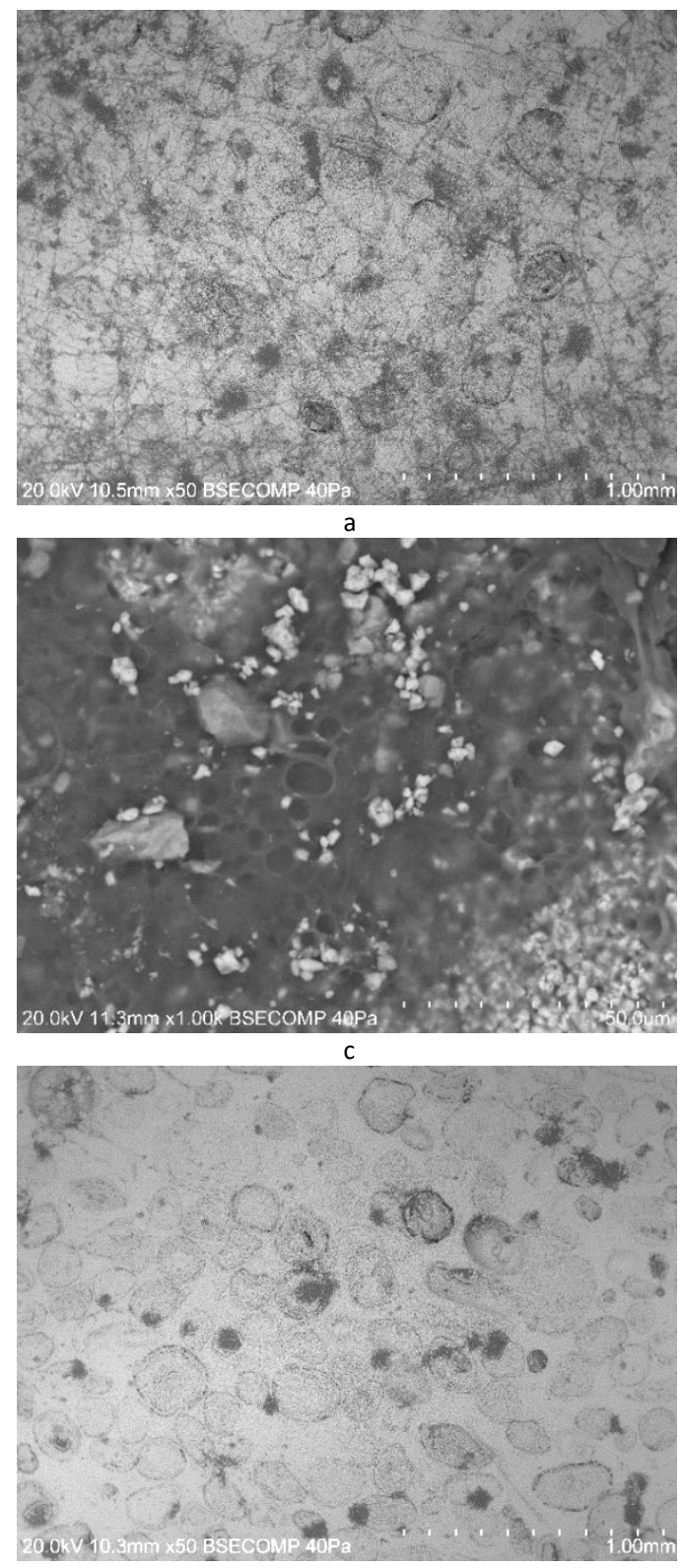

e

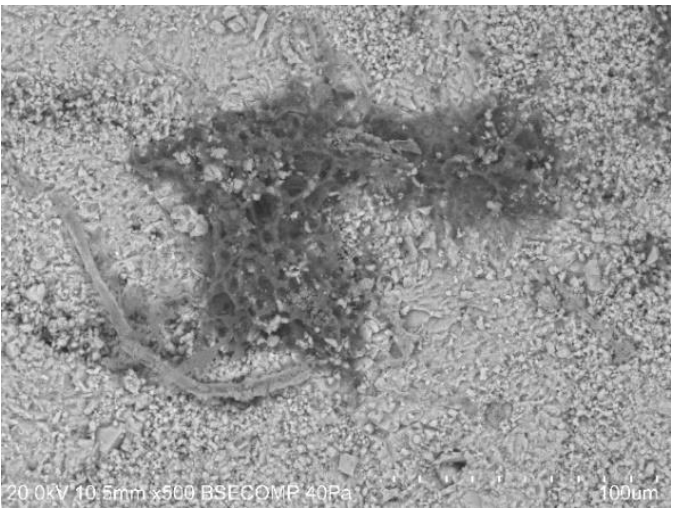

g
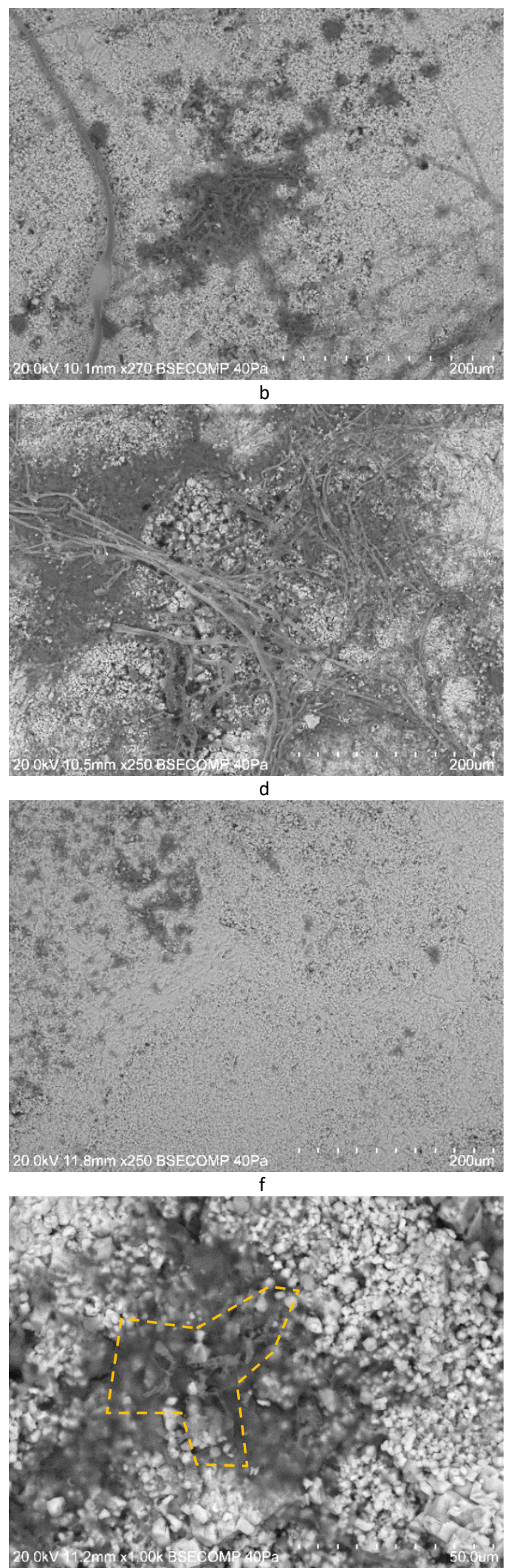

$\mathrm{h}$

Figure 5. SEM of the tablets before and after plasma treatment: a. abundant microbes on the area shielded from plasma; $b$. various species of microbials on the untreated sample; c. circular structured cells on the untreated sample; d. filamentous microorganism on the sample shielded from plasma; e. sample treated with $15 \mathrm{~W}$ plasma for $30 \mathrm{~min}$; f. sample treated with $30 \mathrm{~W}$ plasma for $15 \mathrm{~min}$; g. distorted and damaged cells after $15 \mathrm{~W} 120$ min of plasma treatment; h. microorganism debris (circuled by yellow dash) on the sample treated with $45 \mathrm{~W} 30 \mathrm{~min}$. 


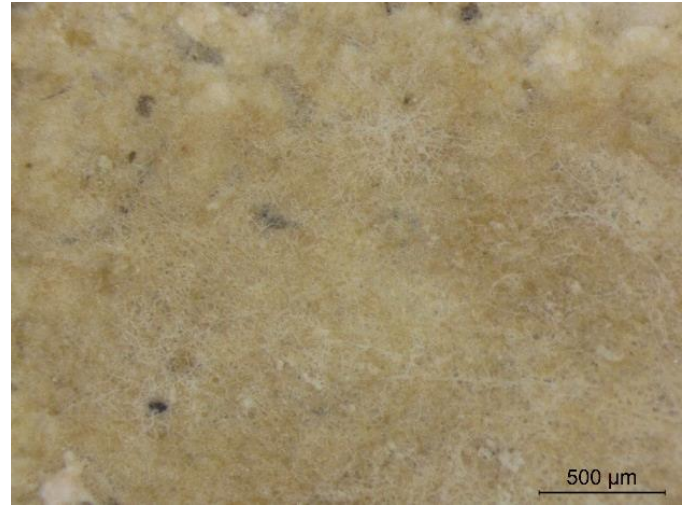

a
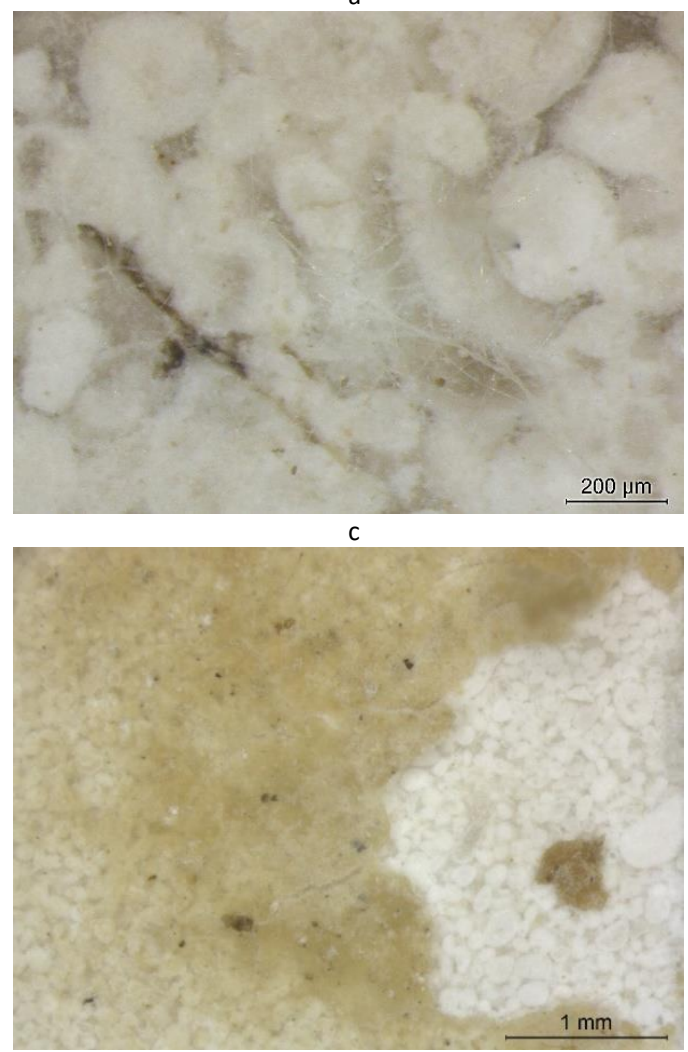

e

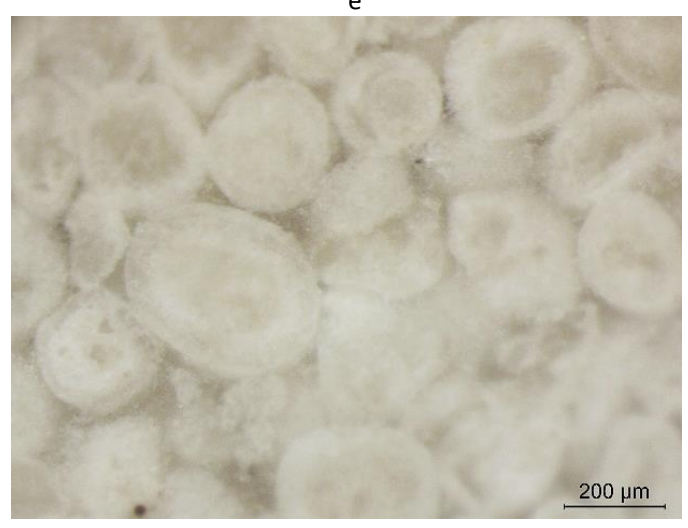

g

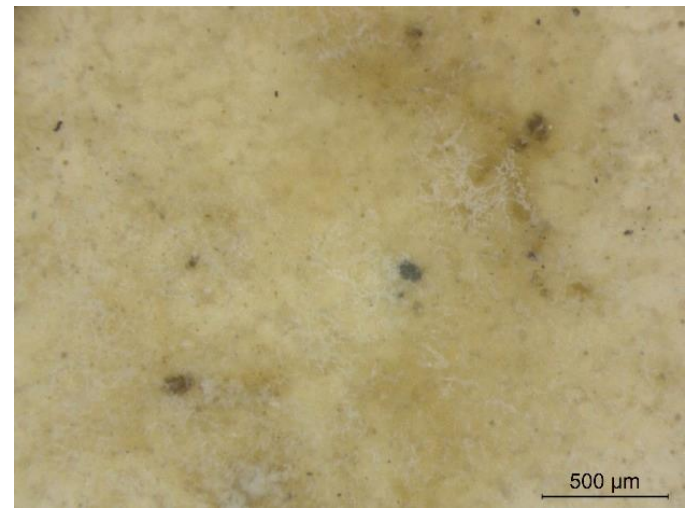

b

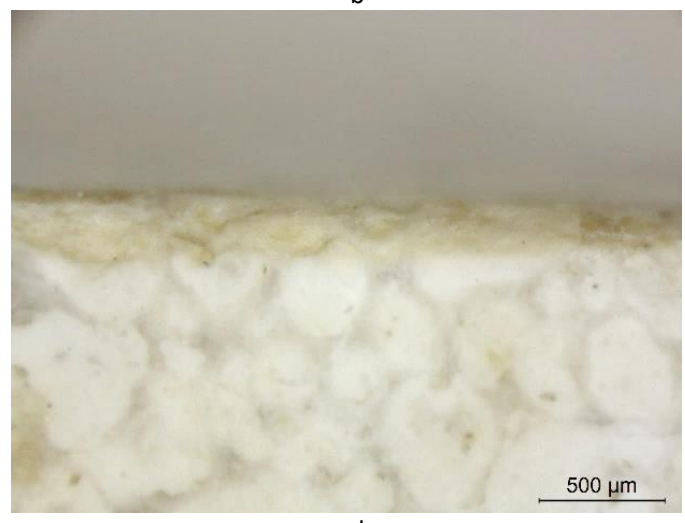

d

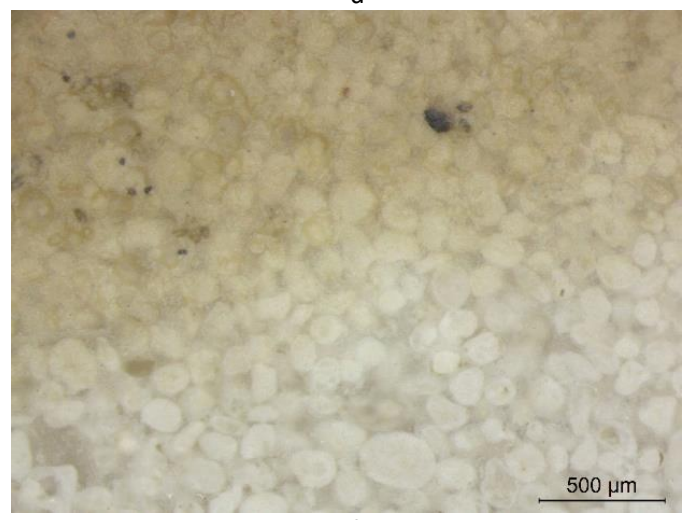

f

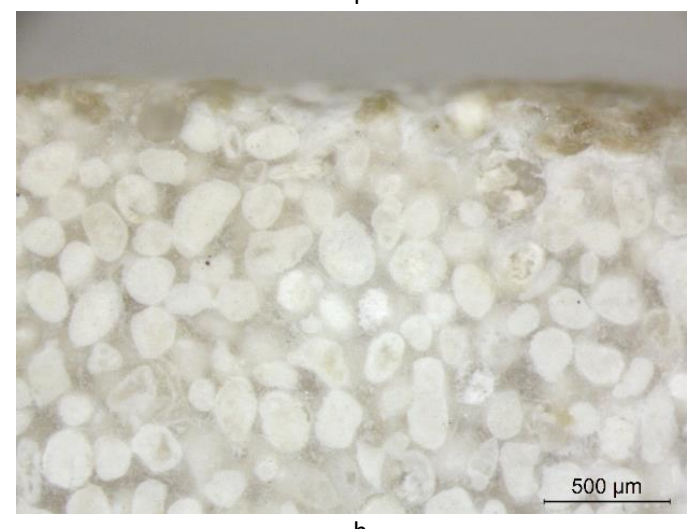

h

Figure 6. Bright field microscope photo of the sample tablets: a. an area covered by thick biofilm before plasma treatment; b. coloured biofilm and black mildews on the stones before plasma treatment; $c$. filamentous microorganism on the limestone before plasma treatment; $d$. the edge of tablet before plasma treatment; e. thick biofilm cracked and detached from the substrate after plasma treatment (15 W, $30 \mathrm{~min}$ ); f. lightened colour of the biofilm and partially faded mold spots (circled by green dash) after plasma treatment (100 W, $15 \mathrm{~min}$ ); g. filamentous microorganism significantly diminished after plasma treatment (30 W, $15 \mathrm{~min})$; h. the edge of tablet after plasma treatment (15 W, $30 \mathrm{~min}$ ). 
Table 3. Cell viability index of treated and untreated samples.

\begin{tabular}{lcc}
\hline Plasma etching parameters of the sample & CVI & Cell viability (\%) \\
\hline untreated sample & $0.1047 \pm 0.0293$ \\
autoclave sterilized sample & $0.0000 \pm 0.0047$ \\
plasma etching $\operatorname{Ar} 30 \mathrm{sccm}, \mathrm{O}_{2} 70 \mathrm{sccm}, 15 \mathrm{~W}, 15 \mathrm{~min}$ & $0.0035 \pm 0.0047$ \\
plasma etching $\operatorname{Ar} 30 \mathrm{sccm}, \mathrm{O}_{2} 70 \mathrm{sccm}, 15 \mathrm{~W}, 30 \mathrm{~min}$ & $-0.0024 \pm 0.0016$ \\
plasma etching $\operatorname{Ar} 30 \mathrm{sccm}, \mathrm{O}_{2} 70 \mathrm{sccm}, 15 \mathrm{~W}, 45 \mathrm{~min}$ & $-0.0012 \pm 0.0047$ \\
plasma etching $\operatorname{Ar} 30 \mathrm{sccm}, \mathrm{O}_{2} 70 \mathrm{sccm}, 30 \mathrm{~W}, 15 \mathrm{~min}$ & $0.0037 \pm 0.0025$ \\
plasma etching $\mathrm{Ar} 30 \mathrm{sccm}, \mathrm{O}_{2} 70 \mathrm{sccm}, 45 \mathrm{~W}, 15 \mathrm{~min}$ & $0.0027 \pm 0.0037$ \\
\hline
\end{tabular}

\subsection{Cell Viability}

Cell viability index test (CVI) was carried out on areas with the same size in treated and untreated samples. Results are shown in Table 3 where the $\%$ of cell viability is referring to the untreated sample. Another sample underwent sterilization by remaining in autoclave at $120^{\circ} \mathrm{C}$ for $30 \mathrm{~min}$, to compare with the effect of plasma cleaning.

Set the cell viability of the sterilized tablet as $0 \%$ and that of the untreated tablet as $100 \%$. It can be seen that samples underwent the plasma etching with parameters of Ar $30 \mathrm{sccm}$, $\mathrm{O}_{2} 70 \mathrm{sccm}, 15 \mathrm{~min}$ duration, input power $15 \mathrm{~W}, 30 \mathrm{~W}, 45 \mathrm{~W}$, presented $2.5 \% \sim 3.5 \%$ cell viability. Under $15 \mathrm{~W}$ input working power, when the plasma treatment time was extended to $30 \mathrm{~min}$ and $45 \mathrm{~min}$, cell viability became even lower than the one after autoclave sterilization.

\section{CONCLUSIONS}

This research aims to discuss the performance of lowpressure plasma etching in the removal of microbial biofilm on building limestones. FTIR, SEM, optical microscope, and CVI test were used to assess the etching results. Results indicated that, with an input power of $15 \sim 45 \mathrm{~W}$ and etching times of $30 \sim 60$ min, plasma etching is able to efficiently remove sugar compounds from limestone surfaces, thus preventing microorganisms growth on the stone by removing their main nutrients supplies. In addition, 15 100 W plasma discharge can damage the microorganism by destructing the cell structures, eventually causing the removal of filamentous microbes, rupture of circular microbial cells and detachment of biofilm. CVI test provides evidence that plasma cleaning is comparable with autoclave sterilization with respect to its ability to kill microbes. In the cleaning protocol used in this study, Ar functioned as dry etching source and $\mathrm{O}_{2}$ contributes to the oxidation of organic substance. Considering the short processing time, low input power, and the advantages of being non-toxic and ecofriendly, plasma cleaning can be considered a promising tool for conservation of ancient stone monuments in reducing the risk of biodegradation of their building materials.

\section{ACKNOWLEDGEMENT}

The research has received funding from the European Union's Horizon 2020 research and innovation programme under the Marie Skłodowska-Curie grant agreement $\mathrm{N}^{\circ} 766311$ (ED-ARCHMAT project - ESR1).

\section{REFERENCES}

[1] N. Schiavon, G. Chiavari, D. Fabbri, Soiling of limestone in an urban environment characterized by heavy vehicular exhaust emissions. Environmental Geology 46(3) (2004), pp. 448-455. DOI: $\underline{10.1007 / \mathrm{s} 00254-004-1046-8}$

[2] A. T. Caldeira, N. Schiavon, G. Mauran, C. Salvador, T. Rosado, J. Mirão, A. Candeias, On the biodiversity and biodeteriogenic activity of microbial communities present in the hypogenic Environment of the Escoural Cave, Alentejo, Portugal. Coatings 11(2) (2021), 209.

DOI: $\underline{10.3390 / \text { coatings } 11020209}$

[3] Y. Ding, C. S. C. Salvador, A. T. Caldeira, E. Angelini, N. Schiavon, Biodegradation and microbial contamination of limestone surfaces: An experimental study from Batalha Monastery, Portugal. Corros. Mater. Degrad. 2 (2021), pp. 31-45. DOI: $10.3390 / \mathrm{cmd} 2010002$

[4] B. T. Gemeda, R. Lahoz, A. T. Caldeira, N. Schiavon, Efficacy of laser cleaning in the removal of biological patina on the volcanic scoria of the rock-hewn churches of Lalibela, Ethiopia. Environmental earth sciences $77(2)$ (2018), pp. 1-12. DOI: $10.1007 / \mathrm{s} 12665-017-7223-3$

[5] R. Tiňo, K. Vizárová, F. Krčma (2019). Plasma surface cleaning of Cultural Heritage objects. In Nanotechnologies and Nanomaterials for Diagnostic, Conservation and Restoration of Cultural Heritage (pp. 239-275). Elsevier.

DOI: $\underline{10.1016 / \text { B978-0-12-813910-3.00011-2 }}$

[6] S. K. Rutledge, B. A. Banks, M. Cales (1995). Atomic oxygen treatment for non-contact removal of organic protective coatings from painting surfaces. MRS Online Proceedings Library 352(1), pp. 161-166. DOI: $10.1557 /$ PROC-352-161

[7] S. Voltolina, C. Aibéo, T. Cavallin, E. Egel, M. Favaro, V. Kamenova, L. Nodari, A. Pavlov, I. Padova, S. Simon, P. Scopece, E. V. Falzacappa, A. Patelli, Assessment of atmospheric plasma torches for cleaning architectural surfaces, Built Herit 4 (2013), pp. 1051-1057.

[8] S. Voltolina, L. Nodari, C. Aibeo, E. Egel, M. Pamplona, S. Simon, E. V. Falzacappa, P. Scopece, A. Gambirasi, M. Favaro, A. Patelli, Assessment of plasma torches as innovative tool for cleaning of historical stone materials, Journal of Cultural Heritage 22 (2016), pp. $940-950$. DOI: $10.1016 /$ j.culher.2016.05.001

[9] S. Grassini, E. Angelini, R. d'Agostino, F: Palumbo, G. M. Ingo, Advanced plasma treatment for cleaning and protecting precious metal artefacts. In Strategies for saving our cultural heritage. Proceedings of the international conference on conservation strategies for saving indoor metallic collections, Cairo. TEI of Athens, Athens, 2007, pp. 127-131.

[10] A. Belkind, S. Gershman, Plasma cleaning of surfaces. Vacuum Coating and Technology (2008), pp. 46-57.

[11] L. Yang, J. Chen, J. Gao, Y. Guo, Plasma sterilization using the RF glow discharge, Applied Surface Science 255(22) (2009), pp. 89608964.

DOI: $\underline{10.1016 / \text { j.apsusc. } 2009.03 .026}$ 
[12] X. Lu, M. Laroussi, V. Puech, On atmospheric-pressure nonequilibrium plasma jets and plasma bullets, Plasma Sources Science and Technology 21(3) (2012), 034005.

DOI: $10.1088 / 0963-0252 / 21 / 3 / 034005$

[13] C. Pflugfelder, N. Mainusch, I. Hammer, W. Viöl, Cleaning of wall paintings and architectural surfaces by plasma, Plasma Processes and Polymers 4(S1) (2007), S516-S521

[14] C. Tendero, C. Tixier, P. Tristant, J. Desmaison, P. Leprince, Atmospheric pressure plasmas: A review, Spectrochimica Acta Part B: Atomic Spectroscopy 61(1) (2006), pp. 2-30.

[15] M. El-Gohary, A. Metawa, Cleaning of architectural bricks using RF plasma. I. Metallica stains, International Journal of Conservation Science 7(3) (2016).

[16] K. Fricke, I. Koban, H. Tresp, L. Jablonowski, K. Schröder, A. Kramer, K. Weltmann, T. von Woedtke, T. Kocher, Atmospheric pressure plasma: a high-performance tool for the efficient removal of biofilms, PloS one 7(8) (2012), e42539.

DOI: $10.1371 /$ journal.pone.0042539

[17] K. Huttenlochner, C. Müller-Renno, C. Ziegler, R. Merz, B. Merz M. Kopnarski, J. Chodorski, C. Schlegel, R. Ulber, Removing biofilms from stainless steel without changing surface properties relevant for bacterial attachment, Biointerphases 12(2) (2017), $02 \mathrm{C} 404$.

DOI: $10.1116 / 1.4982196$

[18] Z. Xu, J. Shen, C. Cheng, S. Hu, Y. Lan, P. K. Chu, In vitro antimicrobial effects and mechanism of atmospheric-pressure He/O2 plasma jet on Staphylococcus aureus biofilm, Journal of Physics D: Applied Physics 50(10) (2017), 105201. DOI: $10.1088 / 1361-6463 /$ aa593

[19] Y. Ding, J. Mirao, P. Redol, L. Dias, P. Moita, E. Angelini, S. Grassini, N. Schiavon, Provenance study of the limestone used in construction and restoration of the Batalha Monastery (Portugal), ACTA IMEKO 10(1) (2021), pp. 122-128. DOI: $10.21014 / \mathrm{acta}$ imeko.v10i1.857

[20] L. Lombardo, N. Donato, S. Grassini, A. Gullino, K. Moulaee, G. Neri, M. Parvis, High Sensitive and Selective minisensor for acetone monitoring, IEEE Transactions on Instrumentation and Measurement 69(6) (2020), pp. 3308-3316. DOI: $\underline{10.1109 / T I M .2020 .2967161}$
[21] C. Noè, C. Tonda-Turo, I. Carmagnola, M. Hakkarainen, M. Sangermano, UV-cured biodegradable methacrylated starch-based coatings, Coatings 11(2) (2021), 127. DOI: $10.3390 /$ coatings 11020127

[22] T. I. S. Rosado, (2014). New methodologies for the characterisation and biodegradation assessment of mural paintings.

[23] L. Dias, T. Rosado, A. Coelho, P. Barrulas, L. Lopes, P. Moita, A. Candeias, J. Mirão, A. T. Caldeira, Natural limestone discolouration triggered by microbial activity-a contribution, AIMS microbiology 4(4) (2018), pp. 594-607. DOI: $10.3934 /$ microbiol.2018.4.594

[24] K. J. Stanienda-Pilecki, The importance of Fourier transform infrared spectroscopy in the identification of carbonate phases differentiated in magnesium content, Spectroscopy 34(6) (2019), pp. 32-42.

[25] D. E. Ortega-Zavala, J. L. Santana-Carrillo, O. Burciaga-Díaz, J. I. Escalante-García, An initial study on alkali activated limestone binders, Cement and Concrete Research 120(2019), pp. 267-278. DOI: $10.1016 /$ i.cemconres.2019.04.002

[26] V. Ramasamy, M. Dheenathayalu, V. Ponnusamy, J. Hemalatha, P. Presannalakshmi, FTIR-characterisation and thermal analysis of natural calcite and aragonite, Indian Journal of Physics 77 (2003), pp. 443-450.

[27] O. Anjos, M. G. Campos, P. C. Ruiz, P. Antunes, Application of FTIR-ATR spectroscopy to the quantification of sugar in honey, Food chemistry, 169 (2015), pp. 218-223. DOI: $10.1016 /$ j.foodchem.2014.07.138

[28] M. H. Mail, N. A. Rahim, A. Amanah, M. H. Khawory, M. A. Shahudin, A. Seeni, FTIR and elementary analysis of Trigona honey, Apis honey and adulterated honey mixtures, Biomedical and Pharmacology Journal, 12(04) (2019), pp 2011-2017. DOI: $10.13005 / \mathrm{bpj} / 1833$

[29] K. Kozłowicz, R. Różyło, B. Gładyszewska, A. Matwijczuk, G. Gładyszewski, D. Chocyk, K. Samborska, J. Piekut, M. Smolewska, Identification of sugars and phenolic compounds in honey powders with the use of GC-MS, FTIR spectroscopy, and X-ray diffraction, Scientific Reports 10(1) (2020), pp. 1-10. DOI: $\underline{10.1038 / s 41598-020-73306-7}$ 